\title{
Frequency of prenatal determination of 13, 18 and 21 trisomies and link with risk factors
}

\section{Vaidas Jotautis ${ }^{1 *}$, \\ Daiva Ambrasien $\dot{e}^{2}$, \\ Danielius Serapinas ${ }^{3}$,}

\section{Astra Vitkauskiene் $\dot{e}^{4}$}

${ }^{1}$ Institute of Cardiology,

Lithuanian University

of Health Sciences,

Sukileliu ave. 17,

LT-50009 Kaunas,

Lithuania

${ }^{2}$ Vytautas Magnus University,

Vileikos str. 8,

LT-44404 Kaunas,

Lithuania

${ }^{3}$ Lithuanian University

of Health Sciences,

Medical Academy,

Department of Pulmonology,

Immunology and Genetics,

Eiveniu str. 2,

Kaunas LT-50009, Lithuania;

Mykolas Romeris University,

Ateities str. 20,

LT-08303 Vilnius,

Lithuania

${ }^{4}$ Lithuanian University

of Health Sciences,

Medical Academy,

Laboratory Medicine Clinic,

Eiveniu str. 2,

LT-50009 Kaunas,

Lithuania
The study was conducted in the Laboratory of the Hospital of Lithuanian University of Health Sciences Kaunas Clinic, in the Laboratory of Clinical Chemistry and Genetics and in the Department of Biology of Vytautas Magnus University. Abnormalities of number of chromosomes are diagnosed from amniotic fluid, which is taken by using an invasive prenatal method - amniocentesis, and modern diagnostic methods such as molecular cytogenetic analysis (FISH) and cytogenetic method, diagnosis of karyotype, by using G-staining method. In order to analyse the main risk factors that determine the frequency of Patau, Edwards and Down syndromes in the analysed group and to evaluate the variety of changeovers of chromosomes structure, the retrospective analysis of patient's case records data was performed. The aforementioned patients were examined in the Hospital of Lithuanian University of Health Sciences Kaunas Clinic in 2007-2011. The received data is processed by using Statistical Package for Social Sciences (T-Test).

The aim of the study is to evaluate, by using cytogenetic and molecular cytogenetic research methods, the frequency of prenatal trisomies determination of the thirteenth (13), the eighteenth (18), and the twenty first (21) chromosomes for the patients, who during 2007-2011 had genetic consultations in the Hospital of Lithuanian University of Health Sciences Kaunas Clinics and to determine the connection between these trisomies and risk factors.

During 2007-2011 11156 patients were examined and 49 (4.2\%) alterations of karyotype were determined, out of which 30 (61\%) are related to Down syndrome, 14 (29\%) to Edwards syndrome and $5(10 \%)$ to Patau syndrome. After studying the data of questionnaires and case records, on the basis of the statistical reliability of data analysis, the influence of the main reproductive factors (abortions, contraceptives) and other risk or environmental factors (smoking, genetic diseases and use of medicines) to fetal anomalies was determined.

Key words: congenital disorders, karyotype, FISH, amniocentesis, teratogenesis, trisomy

*Corresponding author. E-mail: vaidas.jotautis@medicina.lt 


\section{INTRODUCTION}

Congenital disorders very often condition physical development defects and intellectual disability. Therefore, the chromosomes of all newborns, who have certain congenital anomalies (external and internal organs) or who are intellectually disabled, should be analysed. Congenital disorders can be diagnosed at any period of organism development (prenatally and postnatally). If there are members of the family with such diseases, prenatal diagnostics is recommended, which allows to diagnose child's disease prior to birth (Sheets et al., 2010).

Most frequently, different changeovers of chromosomes are noticed in the chromosomes of premature fetal tissues. $15-20 \%$ of all pregnancies are supposed to be aborted, i. e. pregnancies end in a miscarriage and approximately half of such miscarriages are related to the chromosomes number or the changeovers of structure, that are not compatible with life. Various chromosome anomalies are diagnosed for approximately 6-7 newborns out of 1000, i. e. approximately $0.7 \%$ of newborns. The most common anomalies of chromosomes are the changeovers of chromosomes that are related to number of disorders: aneuploidies of the 21st, the 18th, and the 13th chromosomes (Kucinskas, 2001).

This work presents an analysis of congenital disorders that are diagnosed in the Laboratory of the Hospital of Lithuanian University of Health Sciences Kaunas Clinic, in the Laboratory of Clinical Chemistry and Genetics: 1. Down syndrome (trisomy of the 21 chromosome); 2. Edwards syndrome (trisomy of the 18 chromosome); 3. Patau syndrome (trisomy of the 13 chromosome).

The diagnosis is based on noninvasive methods: the investigation of biochemical serum indicators during the first and the second trimester of pregnancy and medical ultrasonography. Biochemical serum analysis is an important noninvasive method - PRISCA which helps to detect the patients, who face higher risk of congenital anomalies. Modern serum analysis helps to identify pregnant women, who face higher risk of neutral tube defect and trisomies of the 21 and the 18 chromosomes (Down syndrome and Edwards syndrome) (Langlois et al., 2013).

Depending on woman's age, her medical, obstetrical, family anamnesis and in case a higher risk of chromosome anomalies is noticed, it is recommended to perform an invasive amniocentesis test, which helps to diagnose the anomalies of chromosomes number and structure, while examining karyotype - the whole view of chromosomes and performing specific FISH tests (Magli et al., 2001; Momsen et al., 2011).

The majority of Lithuanians have a misleading opinion that congenital disorders and all hereditary diseases are a very rare phenomenon. Unfortunately, a child with such a disease can be born in any family. Therefore, the society should know what are the reasons of this phenomenon and what help can be offered to such family. For instance, several tens of children with Down syndrome are born in Lithuania every year. The frequency of this disease among newborns is 1:700. Anually, approximately 30000 babies are born in Lithuania, thus, every year approximately 40 newborns, who have the aforementioned disease, should be born in our country (Utkus, 2011).

Based on the studies, the only obvious feature is the connection between aforementoned aneuploidies and mother's age: a risk to give birth to a child with Down, Edwards or Patau syndromes is much higher for women who are 35-40 years old compared to younger women (Hil, 2009).

\section{MATERIALS AND METHODS}

The study consists of the following stages (Fig. 1):

Stage 1. Noninvasive PRISCA tests are conducted. During the first and the second trimesters of the pregnancy the analysis of biochemical serum indicators and medical ultrasonography are performed. These indicators help to identify pregnant women who have a higher risk to give birth to a newborn 


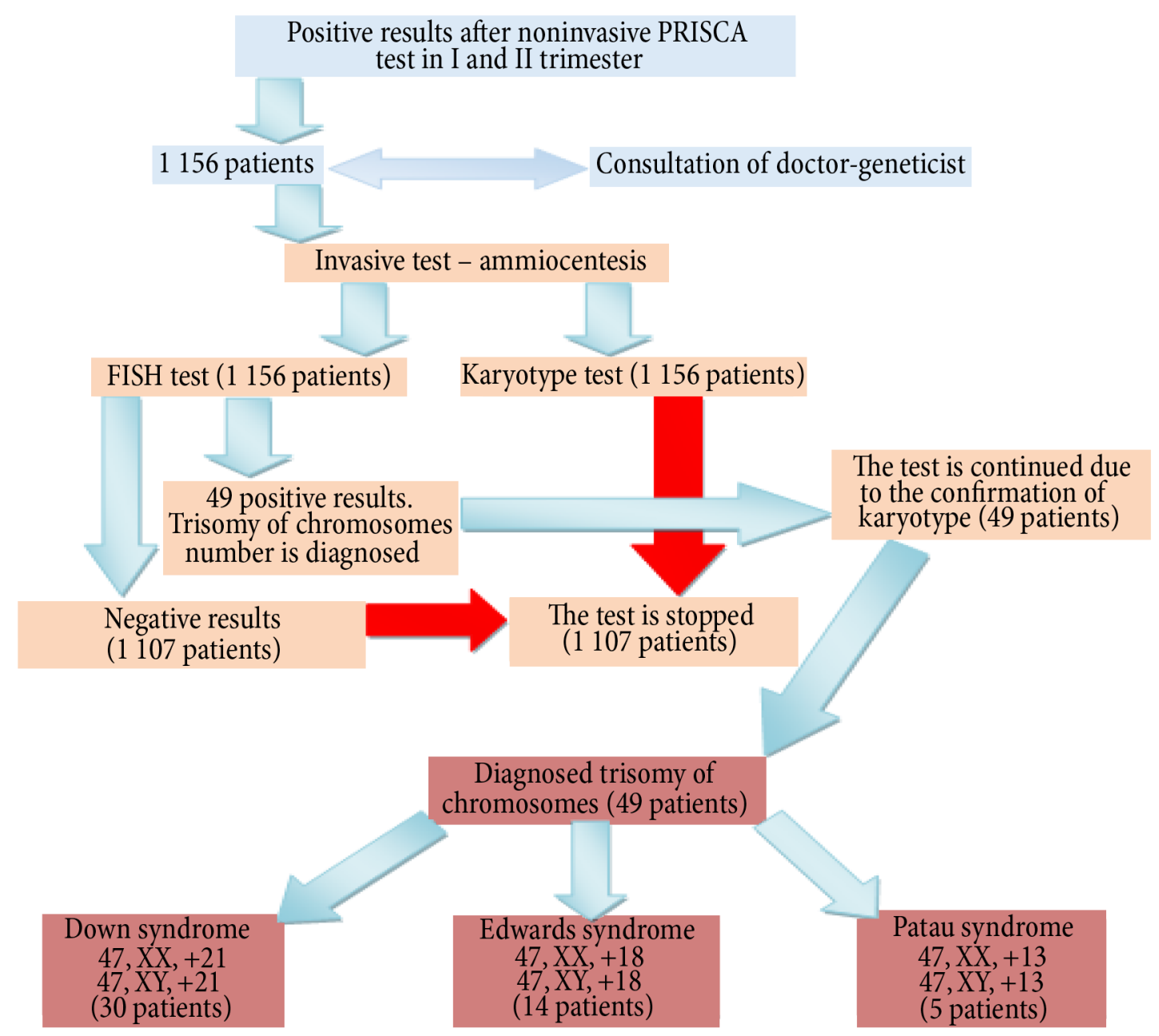

Fig. 1. The scheme of the study

with different chromosomes anomalies (Alexioy, 2009).

Stage 2. Patients, who have a higher risk of PRISCA test results, are consulted by a geneticist.

Stage 3. Patients are offered further opportunities of examination, by specifying the diagnosis with a prenatal diagnostics method - amniocentesis.

Stage 4. FISH tests are carried out (Harada, Korf, 2006). When positive results are received, karyotype is proved by using a method of karyotype test. This stage of analysis is discussed in the present study.

Investigative material of Stage 4 of the analysis is amniotic fluid with fetal cells, that provide information about the fetal chromosomes. Amniotic fluids are taken from the womb during 16-22 weeks by using invasive prenatal diagnostics (a method of amniocentesis). The medical procedure is performed by a doctorobstetrician. A thin needle is inserted into a gestational sac of amniotic fluids through the stomach and womb lining. After taking amniotic fluid (approximately 10-15 ml) into two onetime syringes, the needle is taken out. Amniotic fluids should be without blood addition. In one hour from taking, the sample is delivered to the laboratory. The temperature should be $18-25^{\circ} \mathrm{C}$ (Harper, 2010).

Amniocytes, collected in the laboratory, are divided into two parts: amniocytes for the molecular cytogenetic FISH test $(5-8 \mathrm{ml})$ that should help to identify the concrete chromosome with its specific symptom and 5-10 $\mathrm{ml}$ of amniocytes for the cytogenetic test that should help to identify the whole karyotype. 
Preparations are prepared under a detailed report, which is confirmed by the Hospital of Lithuanian University of Health Sciences Kaunas Clinic. The procedures also follow the rules of good laboratory practice.

After performing the analysis mentioned in Stages 1-3, during 2007-2011 1156 patients, who had a higher risk to give birth to a newborn with different chromosomes anomalies, were identified. The opportunities of further investigation were offered to the patients, specifying the diagnosis by using the method of invasive prenatal diagnostics - amniocentesis.

\section{Preparation of a questionnaire}

In order to analyse the major risk factors that condition the development of Patau, Edwards and Down syndromes in the analysed group, the retrospective analysis of the case records of the patients, who were examined in the Hospital of Lithuanian University of Health Sciences Kaunas Clinic in 2007-2011, was carried out. It was performed with the help of a questionnaire, which was prepared in collaboration with a doctor-geneticist and by taking into consideration the recommendations for similar questionnaires.

The intervention group consisted of pregnant women who experienced the invasive diagnostic procedure - amniocentesis. In order to achieve as informative results as possible, the intervention group was formed of pathological and control groups. 32 patients were analysed in the pathological group and 40 patients were analysed in the control group. Case records were found in archives and analysed. The received data was processed with Statistical Package for Social Sciences by using a method of statistical data analysis - T-Test. In addition, after comparing groups of nominal variables, crosstabulations were created.

\section{RESULTS}

In order to diagnose the anomalies of chromosomes number prenatally, during the study by using molecular cytogenetic FISH method and cytogenetic method of karyotype test (analysis system Cyto Vision, Leica Biosystems, Germany), the material of amniocytes of 1156 patients was tested. The analysis of the research carried out during 2007-2011 was performed in Laboratory Medicine Clinic of Kaunas Clinic and Laboratory of Clinical Chemistry and Genetics. 49 patients were diagnosed with the pathology of trisomies of chromosomes (13, 18 and 21). This number comprises $4.2 \%$ of investigatives, who fell into the risk group, i. e. a foetus of every 24 th woman was diagnosed with the anomaly of chromosome that is related to Down $(47, \mathrm{XX},+21 ; 47, \mathrm{XY},+21)$ Edwards $(47, \mathrm{XX},+18 ; 47, \mathrm{XY},+18)$ and Patau (47, XX, +13; 47, XY, +13) syndromes. 30 patients of investigative group (1156 patients) were diagnosed with Down syndrome (2.6\%), 14 were diagnosed with Edwards syndrome $(1.3 \%)$ and 5 were diagnosed with (Patau syndrome (0.4\%) (Table).

Table. The frequency of diagnosed syndromes in 2007-2011

\begin{tabular}{|c|c|c|c|c|c|c|}
\hline \multirow{2}{*}{ Syndrome } & 2007 & 2008 & 2009 & 2010 & 2011 & \multirow{2}{*}{$\begin{array}{c}\text { In total } \\
2007-2011\end{array}$} \\
\hline & $\mathrm{n} / \%$ & $\mathrm{n} / \%$ & $\mathrm{n} / \%$ & $\mathrm{n} / \%$ & $\mathrm{n} / \%$ & \\
\hline Down syndrome & $4 / 2.9 \%$ & $3 / 1.3 \%$ & $9 / 2.6 \%$ & $5 / 2.3 \%$ & $9 / 4.1 \%$ & $30 / 61 \%$ \\
\hline Edwards syndrome & $2 / 1.5 \%$ & $5 / 2.1 \%$ & $3 / 0.87 \%$ & $3 / 1.4 \%$ & $1 / 0.45 \%$ & $14 / 29 \%$ \\
\hline Patau syndrome & $0 / 0 \%$ & $1 / 0.4 \%$ & $2 / 0.58 \%$ & $0 / 0 \%$ & $2 / 0.9 \%$ & $5 / 10 \%$ \\
\hline $\begin{array}{c}\text { The total number of } \\
\text { investigatives }\end{array}$ & 136 & 237 & 345 & 216 & 220 & 1154 \\
\hline $\begin{array}{c}\text { The total number of } \\
\text { pathologies }\end{array}$ & $6 / 4.4 \%$ & $9 / 3.8 \%$ & $14 / 4.1 \%$ & $8 / 3.7 \%$ & $12 / 5.5 \%$ & $49 / 4.2 \%$ \\
\hline
\end{tabular}

$\mathrm{n}$ - diagnosed trisomy, \% - the set proportion of trisomies shows how many new cases of the disease are diagnosed during a year compared to the number of all investigatives every year 
The determination of statistically reliable risk factors that influence foetus anomalies

The analysis of 32 patients, who during this period gave birth to newborns with aneuploidies of $+13,+18,+21$ chromosomes, case records and questionnaires was carried out. Equally, the analysis of case records and questionnaires of 40 patients, who belonged to the contol group, was performed. The aforementioned patients were examined with invasive tests.

After analysing the data of questionnaires and the data of analysis of case records and after processing the data with Statistical Package for Social Sciences with reference to statistical reliability (when $\mathrm{P}<0.05$ is totally reliable), the influence of the main reproductive factors (abortions, contraceptives) or environmental factors (smoking, genetic diseases and use of medicines) to fetal anomalies was determined.

$6 \%$ of patients, who belonged to the pathological group, used hormonal contraception after conception, $16 \%$ of patients used hormonal contraception less than three months prior to pregnancy, $34 \%$ used it more than three months prior to pregnancy, and only $44 \%$ of patients did not use hormonal contraception. Even $90 \%$ of patients, who belonged to the control group, did not use hormonal contraception, and only $10 \%$ of patients used it more than three months prior to pregnancy. The results presented in Fig. 2 show a direct connection between the reproductive factors, such as use of hormonal preparation, and fetal anomalies.

Abortion is another important factor which influences reproduction. The results presented in Fig. 3 show that $31 \%$ of patients, who belonged to the pathological group, had at least one abortion prior to the present conception. Whereas the control group had only $24 \%$ of abortions. Thus abortions also prove that there is a connection with aneuploidies.

Smoking is a risk and environmental factor which influences the anomalies of fetal chromosomes. The results are presented in Fig. 4. After analysing the questionnaires, it was noticed that $3 \%$ of patients in the pathological group used tobacco products after the conception, $13 \%$ used to smoke before the pregnancy, and $84 \%$ of patients did not use tobacco products. Meanwhile the patients, who belonged to the control group, did not use tobacco at all, and $3 \%$ of patients used to smoke only before the conception. $97 \%$ are composed of patients who have never smoked. Based on the statistical reliability, the use of tobacco is a very informative risk factor which is related to the diagnosed anomalies.

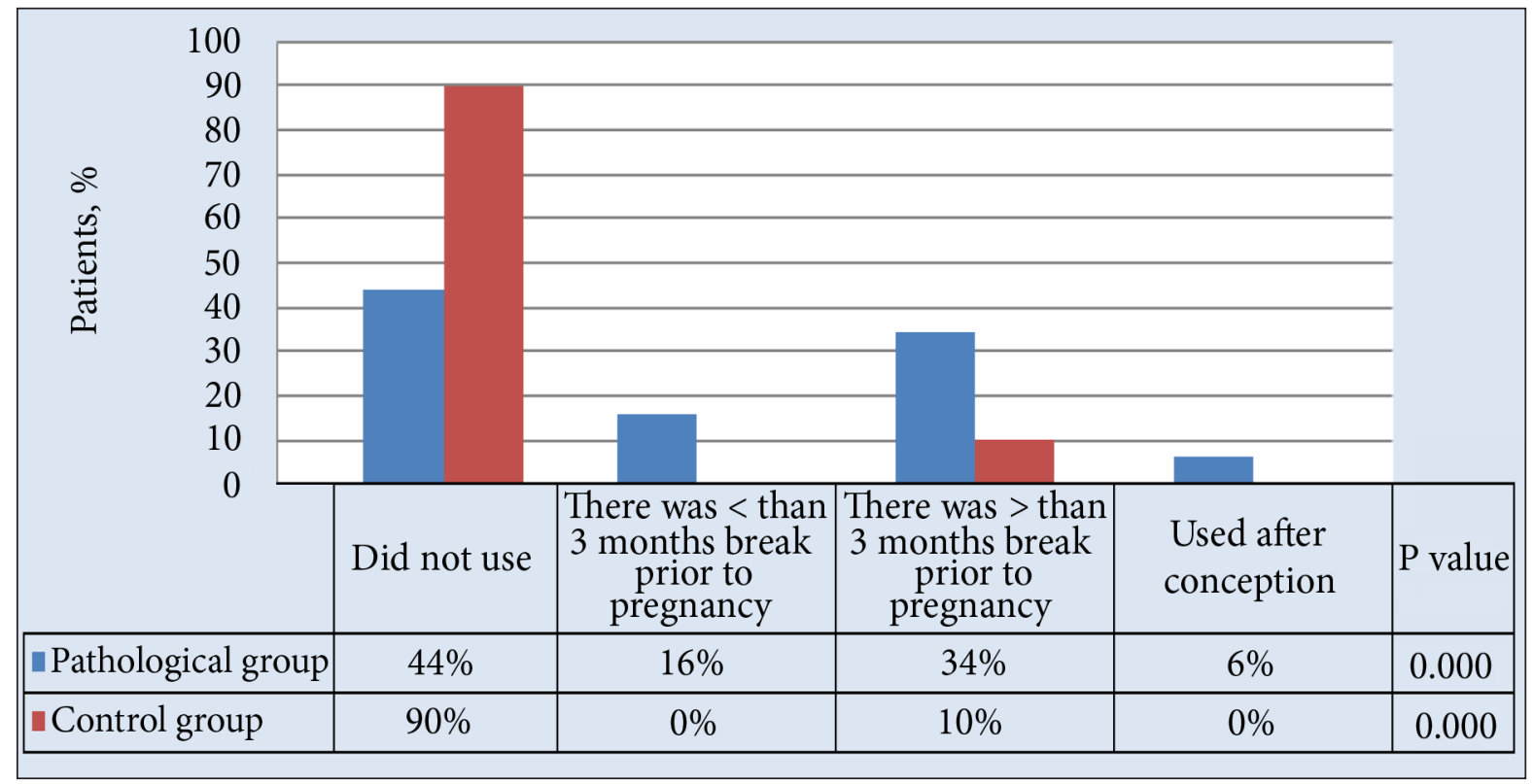

Fig. 2. The proportion of hormonal contraception use in the pathological and control group (\%) 


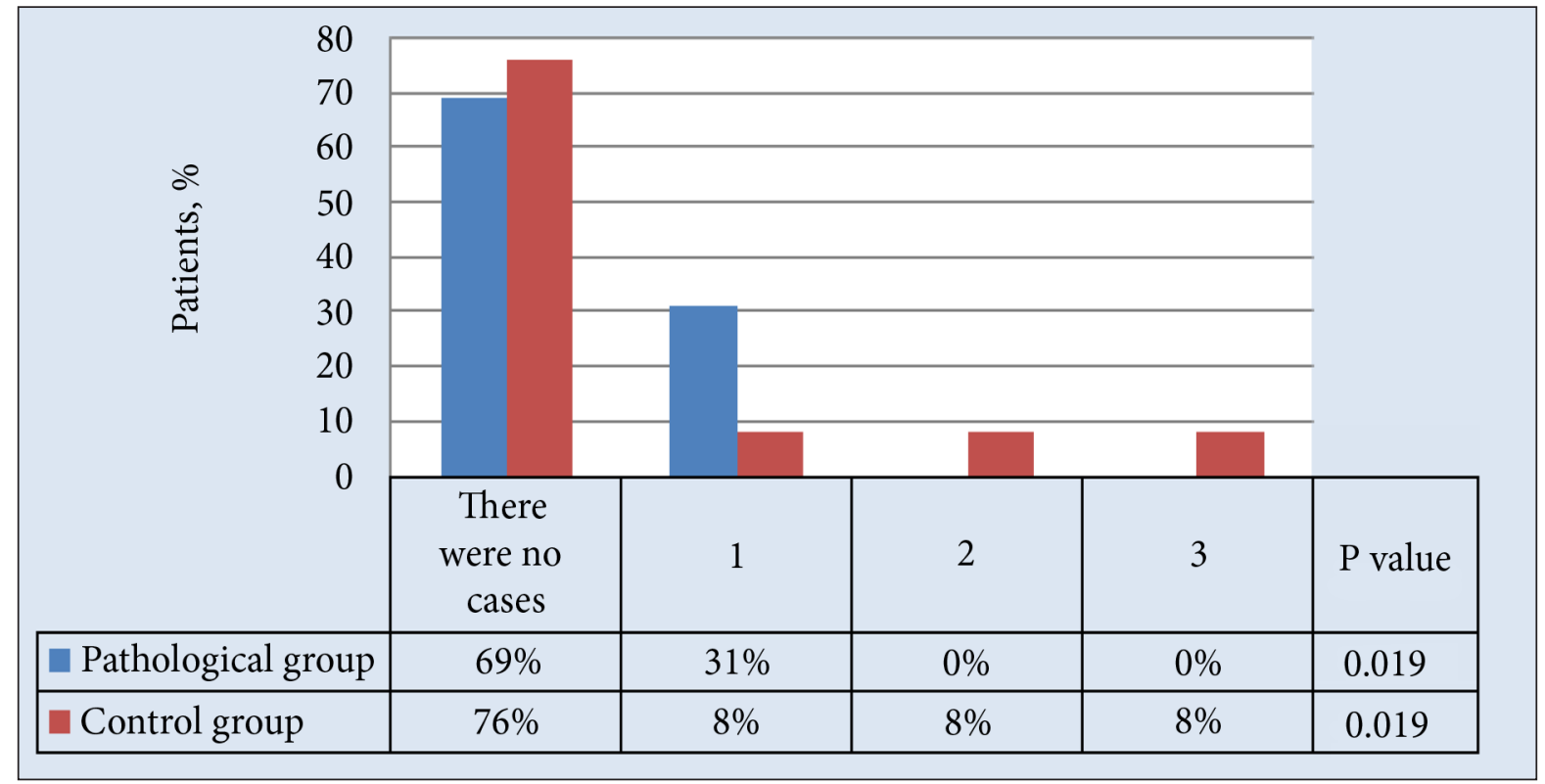

Fig. 3. The proportion of abortions in the pathological and control group (\%)

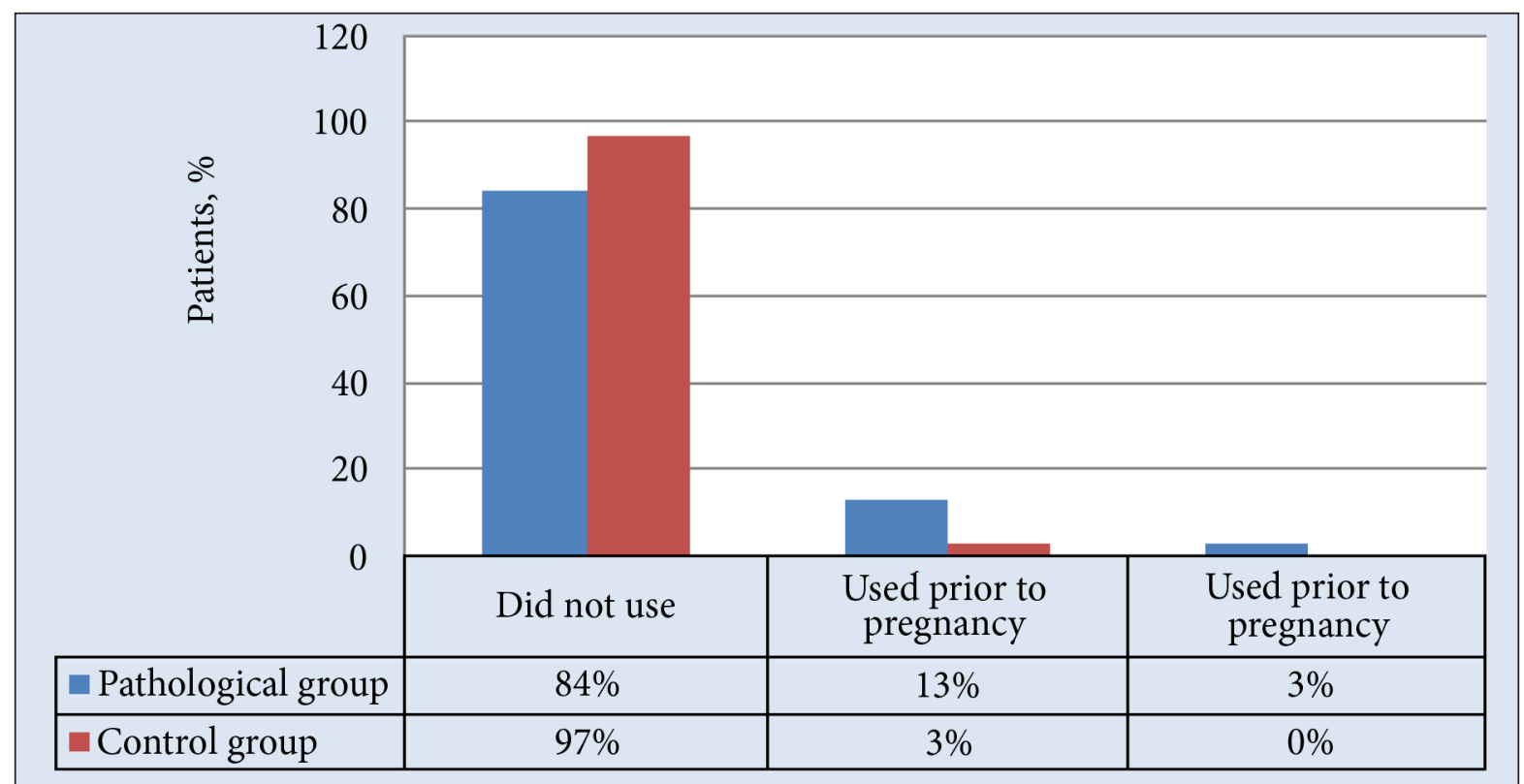

Fig. 4. The proportion of tobacco use in the pathological and control group (\%)

The results of the present study presented in Fig. 5 show that the use of medicines (a risk and environmental factor) can influence fetal anomalies. Even $25 \%$ of patients, who belonged to the pathological group, used medicines, out of whom $10 \%$ used medicines less than 3 months prior to pregnancy, and $15 \%$ used medicines after conception. The main medicines used by patients after the conception were tiroxin, trileptal, medrol, lamictal and various antidepresants. Merely $16 \%$ of patients used medicines in the control group, out of whom $10 \%$ used medicines less than 3 months prior to pregnancy and only $3 \%$ of patients, who had recurrent central nervous system strokes (epilepsy), used lamictal - medicine, which affects central nervous system, after the conception. Thus the present diagram also shows a distinct connection between a risk factor - use of medicines - and the investigative pathologies. 
Genetic diseases are another risk and environmental factor which influences aneuploidies. The results presented in Fig. 6 show that $9 \%$ of patients in the pathological group who were diagnosed with aneuploidies were related to genetic diseases: $3 \%$ of patients, whose husband's brother's family gave birth to a dead girl, $3 \%$ of patients, whose husband's sister gave birth to a child with Down syndrome, and 3\% of patients, whose sister also gave birth to a child with Down syndrome.

Summarizing the results of the study, it was established that during 2007-2011, after the analysis of 1159 patients by using cytogenetic and molecular cytogenetic methods, 49 cases of anomalies of chromosomes number were

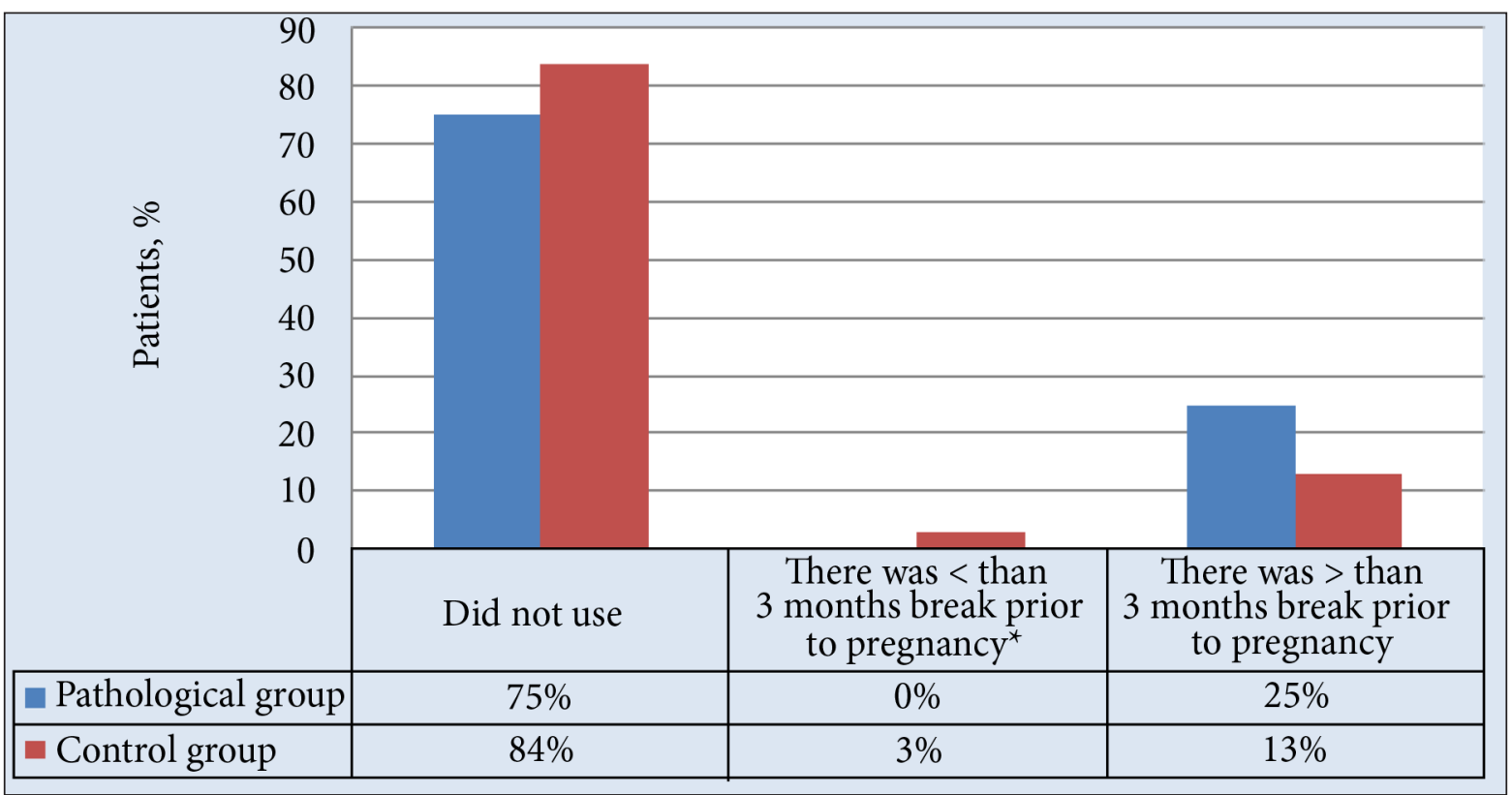

Fig. 5. The proportion of use of medicines in the pathological and control group (\%) ${ }^{\star}<3$ months pause (including the moment of conception and pregnancy)

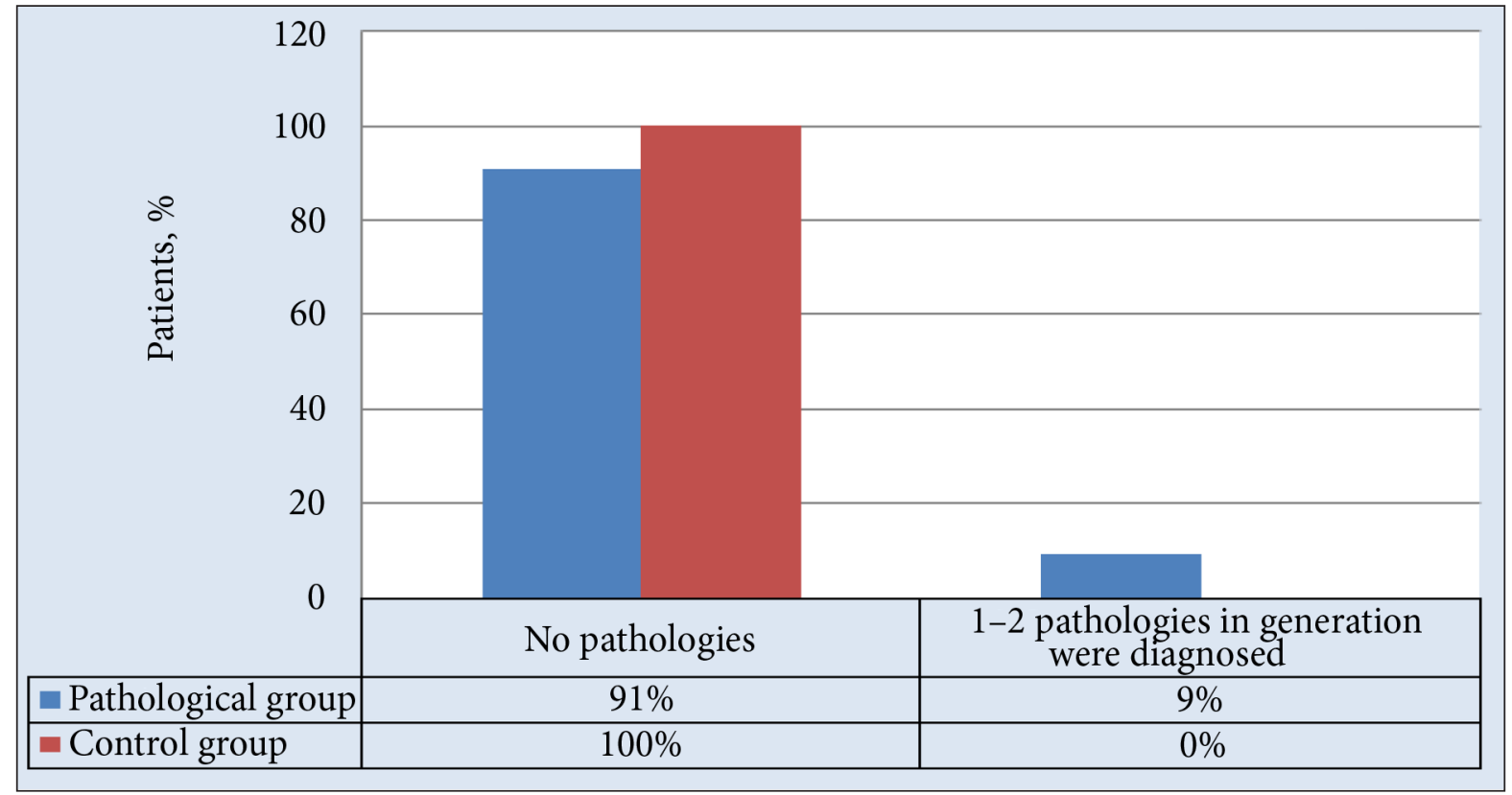

Fig. 6. The proportion of genetic diseases in the pathological and control group (\%) 
identified. 30 patients (61\%) were diagnosed with the additional 21st chromosome, 14 patients (29\%) were diagnosed with the additional 18th chromosome, and 5 patients (10\%) were diagnosed with the additional 13th chromosome. Thus, the frequency of diagnosed trisomies conforms to the data presented in literature (Down syndrome is one of the most frequently diagnosed trisomies of chromosomes, Patau syndrome is the most seldom diagnosed) (Torrelo, 2010; Bredaki, 2011).

The analysis of case records and questionnaires of the control group and patients, who during this period gave birth to newborns with $+13,+18,+21$ aneuploidies of chromosomes, was carried out. After analysing and processing the obtained data, the influence of the main reproductive factors and other risk and environmental factors to fetal anomalies was established.

\section{DISCUSSION}

49 cases of anomalies of chromosomes number were identified in the investigative material of 1159 patients. Out of 49 pathological cases 30 patients $(61 \%)$ were diagnosed with the additional 21st chromosome, 14 patients (29\%) were diagnosed with the additional 18 th chromosome, and only 5 patients $(10 \%)$ were diagnosed with the additional 13th chromosome. 19-34 years old patients were diagnosed with $31.5 \%$ of fetal anomalies cases, and 35-44 years old patients were diagnosed even with $68.5 \%$ of fetal anomalies cases.

The obtained results of the study conform to the data presented in literature. Down syndrome is one of the most frequently diagnosed trisomies of chromosomes (the frequency among the newborns is 1:700), and Patau syndrome is the most seldom diagnosed (the frequency is 1:10000) (Torrelo, 2010; Bredaki, 2011).

In addition, the obtained results of the study proved the results of the earlier studies that 3540 years old women had several times higher risk to give birth to a newborn with Down,
Edwards or Patau syndrome compared with younger women (Hil, 2009).

The largest number of patients was 345 , out of which 14 patients (4.1\%) were diagnosed with fetal anomalies in 2009. In 2008, 237 patients were examined, out of which nine (3.8\%) were diagnosed with fetal anomalies, in 2010, 216 patients were examined and 3.7\% of anomalies (i. e. one anomaly less) were diagnosed. During 2011220 patients were examined and 12 pathologies (5.5\%) were diagnosed. The least number of patients was tested in 2007 (136 patients), but six pathologies (4.4\%) related to Down, Edwards, and Patau syndromes were diagnosed.

Similar studies for the evaluation of frequency of diagnosis of Down, Edwards and Patau syndromes were carried out in the Medical Genetics Centre of Vilnius University Hospital Santariškių Klinikos. When comparing the data of our study collected by using invasive diagnostics methods (FISH and the diagnosis of karyotype by using G-staining with the studies carried out in the Medical Genetics Centre of Vilnius University Hospital Santariškių Klinikos, it can be stated that the statistics of trisomies diagnostics is similar. The most frequently diagnosed is Down syndrome (47, XX, +21; 47, XY, +21) which comprises $61 \%$ in the investigative group and $63 \%$ in the Medical Genetics Centre of Vilnius University Hospital Santariškių Klinikos. The second most frequent syndrome is Edwards syndrome (47, $\mathrm{XX},+18 ; 47, \mathrm{XY},+18)$ which was diagnosed to $29 \%$ of patients in the investigative group and to $31 \%$ of patients in the Medical Genetics Centre of Vilnius University Hospital Santariškiu Klinikos. The most seldom diagnosed syndrome is Patau syndrome $(47, \mathrm{XX},+13 ; 47$, $\mathrm{XY},+13$ ), only $10 \%$ of investigatives were diagnosed with it in our study and 6\% of patients were diagnosed with it in the Medical Genetics Centre of Vilnius University Hospital Santariškių Klinikos (Kasnauskienè, Šimkonytè, Šilkūnas, 2009).

In another study, which was performed in Poland, in the Clinic of Obstetrics and Gynaecology, Edwards syndrome was ana- 
lysed. The frequency of diagnosis was 3.45\% (Chuchracki et al., 2012), whereas in our study the frequency of Edwards syndrome was 1.3\%. Due to different number of Lithuanian and Polish population, the results show an equal increase. The tendentious data of analysis is noticed in Germany, Estonia, and Great Britain (Iacobini, Lotersztein, 2011; Reddy et al., 2012; Hultén et al., 2013).

\section{CONCLUSIONS}

After carrying out the analysis of cytogenetic and molecular cytogenetic FISH test results of 1156 patients' amniotic fluids, 49 (4.2\%) pathological cases were diagnosed: 13 (0.4\%), $18(1.3 \%)$, and $21(2.6 \%)$ trisomies of chromosomes.

After analysing 49 pathological cases, 30 patients were diagnosed with Down syndrome (61\%), 14 patients were diagnosed with Edwards syndrome (29\%), and 5 patients were diagnosed with Patau syndrome (10\%). The statistics of pathologies coincides with the data presented in literature.

After summarizing the results of questionnaires (according to the data of case records) and analysing them by using Statistical Package for Social Sciences (statistical reliability $\mathrm{P}<0.05)$ the main reproductive factors were determined (abortions, contraceptives) and other risk and environmental factors (the use of tobacco, genetic diseases, the use of medicines) that influenced the development of fetal anomalies.

Received 30 April 2014 Accepted 28 May 2014

\section{References}

1. Sheets KB, Blythe G. Crissman, Cori D. Feist, Susan L. Sell, Lisa R. Johnson, Kelly C. Donahue, Diane Masser-Frye, Gail S. Brookshire, Amanda M. Carre, Danielle LaGrave, Campbell K. Brasington. Practice Guidelines for Communicating a Prenatal or Postnatal Diag- nosis of Down Syndrome. Nat Soc Gen Couns 2011; 42-60. ISSN: 1059-7700.

2. Kučinskas V. Genetika. Šviesa, 2001, 173 p. ISBN5-430-03325-1.

3. Langlois S, Brock JA, Wilson RD, Audibert F, Brock JA, Carroll J, Cartier L, Gagnon A, Johnson JA, Langlois S, Macdonald W, Murphy-Kaulbeck L, Okun N, Pastuck M, Senikas V. Current status in non-invasive prenatal detection of Down syndrome, trisomy 18 , and trisomy 13 using cell-free DNA in maternal plasma. Obst Gynaecol Can 2013; 81-125. ISSN: 0300-5577.

4. Magli MC, Gianaroli L, Ferrareti A. Chromosomal abnormalities in embryos. Mol Cell Endocr 2001; 69-82. ISSN: 1874-8057.

5. Momsen G, Sundberg K, Friis-Hansen L, Jorgensen FS. First-trimester risk calculation for trisomy 13,18, and 21: comparison of the screening efficiency between 2 locally developed programs and commercial software. Clin Chemist 2011; 57-72. ISSN: 1530-8561.

6. Utkus A. Asmenų su intelektine negalia genetinio ištyrimo gairès. Rotas, 2011; 283 p. ISSN 1392-3064.

7. Hill P. Down Syndrome Prevalence in the United States. Amer Acad Pediatr 2009; 9-21. ISSN: 1689-2564.

8. Alexioy E, Trakakis E, Kassanos D, Farmakidis G. Predictive value of increased nuchal translucency as a screening test for the detection of fetal chromosomal abnormalities. Department of Mother's and Children's Health, National School of Public Health, Greece. J Matern-Fetal Neonat Medic 2009; 57-72. ISSN: 1476-7058.

9. Harada S, Korf BR. Overview of molecular genetic diagnosis. University of Alabama at Birmingham. Curr Protoc Human Gen 2006; 29-41. ISSN: 1934-8258.

10. Harper P. Practical genetic counseling. Human Genetics at Cardiff University, 2010. 407 p. ISBN: 978-0-340-99069-8.

11. Torrelo A. Patau Syndrome. J Amer Acad Dermatol 2010; 6-15. ISSN: 0190-9622. 
12. Bredaki FE, Matos P, Syngelaki A. Firsttrimester screening for trisomy 21 using alpha-fetoprotein. Fetal Diagn Therap 2011; 8-21. ISSN: 1421-9964.

13. Kasnauskienè J, Šimkonytė E, Šilkūnas M. Prenataliné genetiné diagnostika: dažniausių aneuploidijų nustatymo metodų palyginimas. Medicina 2009; 13-21. ISSN: 0034-1193.

14. Chuchracki M, Janiak J, Ziolkowska K, Sedziak A, Opala T. Edwards syndrome - most frequent indications for genetic amniocentesis. Analysis of the last 5 years. Przegl Lek J 2012; 69-87. ISSN: 0033-2240.

15. Iacobini S, Lotersztein V. Sindrome de Patau. Intramed J 2011; 91-105. ISSN: 1438-8871.

16. Reddy UM, Page GP, Saade GR, Silver RM, Thorsten VR, Parker CB, Pinar H, Willinger M, Stoll BJ, Heim-Hall J, Varner MW, Goldenberg RL, Bukowski R, Wapner RJ, Drews-Botsch CD, Brien BM, Dudley DJ, Levy B. Karyotype versus microarray testing for genetic abnormalities after stillbirth. New Engl J Med 2012; 16-25. ISSN: 0028-4793.

17. Hultén MA, Jonasson J, Iwarsson E, Uppal P, Vorsanova SG, Yurov YB, Iourov IY. Trisomy 21 Mosaicism: We May All Have a Touch of Down Syndrome. Cytogen Genom Res 2013; 16-29. ISSN: 1424:8581.

Vaidas Jotautis, Daiva Ambrasienè, Danielius Serapinas, Astra Vitkauskienè

\section{3, 18 IR 21-OS TRISOMIJOS PRENATALINIO NUSTATYMO DAŽNIS IR SĄSAJA SU RIZIKOS VEIKSNIAIS}

\section{Santrauka}

Mokslinis darbas buvo vykdomas LSMUL Všt Kauno klinikų laboratorinès medicinos klinikoje, klinikinès chemijos ir genetikos laboratorijoje ir VDU biologijos katedroje. Chromosomų skaičiaus anomalijos nustatytos iš vaisiaus vandenų, paimtų pasitelkus invazinị prenatalinị metodą - amniocentezę, taip pat naudojant šiuolaikinius diagnostikos metodus: molekulinị citogenetini - FISH ir citogenetini - kariotipo nustatymas $\mathrm{G}$ metodu. Siekiant išanalizuoti pagrindinius rizikos veiksnius, lemiančius Patau, Edvardso ir Dauno sindromų dažnị analizuojamoje grupeje, bei ịvertinti chromosomų struktūros persitvarkymų įvairovę, atlikta retrospektyvinė 2007-2011 m. LSMUL VšI Kauno klinikose ištirtų pacienčių ambulatorinių kortelių duomenų analizè. Gauti duomenys apdoroti naudojant programini paketą SPSS (T-Test).

Darbo tikslas - taikant citogenetinius bei molekulinius citogenetinius tyrimų metodus įvertinti tryliktos (13), aštuonioliktos (18) bei dvidešimt pirmos (21) chromosomų trisomijos prenatalinio nustatymo dažnumą pacientėms, kurios 20072011 metais kreipèsi dèl genetinès konsultacijos i Lietuvos sveikatos mokslų universitetinę ligoninę Všl Kauno klinikas, ir nustatyti šių trisomijų sąsajas su rizikos veiksniais.

2007-2011 metais ištirtos 1156 pacientès, nustatyti 49 (4,2 \%) kariotipo pakitimai, iš kurių 30 (61 \%) buvo susiję su Dauno sindromu, 14 (29\%) - su Edvardso sindromu bei 5 (10 \%) - su Patau sindromu. Išanalizavus anketinès apklausos, ambulatorinių kortelių duomenis, taip pat remiantis statistiniu patikimumu, buvo nustatytas pagrindinių reprodukcinių veiksnių (něštumo nutraukimų, kontraceptinių preparatų) bei kitų rizikos, aplinkos veiksnių (tabako vartojimo, genetinių ligu chromosominiame medyje, tap pat vaistinių preparatų vartojimo) poveikis vaisiui.

Raktažodžiai: chromosominès ligos, kariotipas, FISH, amniocentezè, teratogenezè, trisomija 